\title{
Assessment of Sustainability Process Using Multi-grade Fuzzy in CV. Indo Jati Utama
}

\author{
Aries Susanty ${ }^{1, *}$, Bambang Purwanggono ${ }^{1}$, and Raudina Huduni ${ }^{1}$ \\ ${ }^{1}$ Department of Industrial Engineering, Diponegoro University, Semarang - Indonesia
}

\begin{abstract}
The first purpose of this study calculated the sustainability index of economic, environmental, social criteria and the sustainability index of the whole manufacturing process conducted by CV. Indo Jati Utama (a wood processing manufacturer in Semarang that sells its products on an export scale). The second purpose of this study calculated the performance importance index of each indicator in each criterion. The last purpose of this study proposed some recommendations to increase the sustainability of the manufacturing process at CV Indo Jati Utama. This study uses the multi-grade fuzzy (MGF) method to calculate sustainability and performance importance index. This study used primary data, collected using questionnaires from five experts (General Manager, Department Head of Marketing, Department Head of Finance, Department Head of Production Planning and Inventory Control, and Department Head of Human Resource). The result of data processing indicated that the sustainability index of economic, environmental, and social and the whole manufacturing production process was $7.48,7.60,7.60$, and 7.50 successively. Moreover, the result of data processing also indicated that the enterprise should increase the performance of five indicators to get more sustainable, namely, flexibility to change, environmental management, green image, employee compensation practices, and employee career development program.
\end{abstract}

Keywords: sustainability index of economic; sustainability index of environmental; sustainability index of social; multi-grade fuzzy; CV. Indo Jati Utama.

\section{Introduction}

The increasing global environmental problems because of overconsumption of natural resources and pollution have directed to political pressure and stronger regulations that push the enterprises to carry out environmentally friendly production processes $[1,2]$. In order to adopt the new government regulations related to the environmentally friendly production process, many enterprises identified sustainable manufacturing as a potential solution. Sustainable manufacturing itself is the subset of the broad topic of sustainable development and the sustainable manufacturing can be achieved by targeting improvements in three orientations, namely material, product design, and manufacturing process [2]. Of the three orientations (product, manufacturing process, and system), the manufacturing process can give more significant impact to the sustainable manufacturing as it directly contributes to the amount of consumption of emissions, energy, and resource [3]. Moreover, to make sure that the enterprise has achieved sustainability level in its manufacturing process, the enterprise needs to make the assessment.

Sustainability assessment is a significant tool to assist in the shift toward sustainability [4-6]. The goal of sustainability assessment is to confirm that "plans and activities conducted by enterprises achieve an optimal impact on sustainable development' [7]. One of the methods can be used by the enterprises to assess the level of sustainability achieved is multi-grade fuzzy (MGF). This technique has been used by several researchers such as Lin et al, Vinodh and Chintha, Vinodh, and Vimal and Vinodh [2, 8-10]. More specifically, Vimal et al [11] use MGF to measure manufacturing process sustainability (process sustainability index). According to Vimal et al [11], MGF method is very simple to understand and according to industrial practitioners' perspective, MGF was found to be a user-friendly approach. Moreover, in the research conducted by Vimal et al [11], the conceptual model for assessing the manufacturing process sustainability consists of three levels. The first level is an enabler (environmental sustainability, social sustainability, and economic sustainability), the second level is criteria, and the third level attributes.

In this study, the assessment of manufacturing process sustainability will conduct at $\mathrm{CV}$. Indo Jati Utama, a wood processing manufacture located at Semarang. This enterprise sells its products on an export scale. As the other wood processing manufacture, $\mathrm{CV}$. Indo Jati Utama also faces a number of obstacles, among others, the supply of legal wood as raw materials, scarcity of raw materials, adaptation of high technology machines, and the amount of wood waste as they fail to carry out the production process more efficiently (especially in the use of raw material). Although the

* Corresponding author: ariessusanty@gmail.com 
result of the preliminary study conducted by the author to the CV. Indo Jati Utama indicated that the enterprises were able to deal with several obstacles; for the more comprehensive result, this study will try to assess the manufacturing process sustainability of $\mathrm{CV}$. Indo Jati Utama encompassed to three enablers (environmental, economic and social) and several indicators in each enabler.

\section{Literature Review}

There is no single definition of sustainable manufacturing since there are many different interpretations of the sustainability concept. Several researchers see the sustainability as an environmental initiative, the other researchers see the sustainability as objective or process, as several combinations of different aspects, or as a conciliation between pillars, etc. [12]. According to Gunasekaran and Spalanzani and Habidin et al $[13,14]$, sustainable manufacturing can be defined as a business model that creates value consistent with the long term preservation and conservation and also enhancement of triple bottom line. Garetti and Taisch [15] defined sustainable manufacturing as an ability to use the raw material effectively, by creating a new product through current technology, regulatory measures and coherent social behaviors with respect to the triple bottom line performance. Not only definition, sometimes sustainable manufacturing expressed by different terminology by a number of researchers. As an example, Ulusoy and Ikiz [16] stated the term sustainable manufacturing with terminology best manufacturing practice; Jackson [17] stated the term sustainable manufacturing with terminology cleaner production; Rusinko and $\mathrm{Hu}[18,19]$ stated the term sustainable manufacturing with terminology green manufacturing; Rahimifard and Clegg, Jafartayari and Nabhani et al [2022] stated the term sustainable manufacturing with terminology sustainable production, etc.

Generally, according to Phama et al [23], the development of sustainable manufacturing can be classified into three-level, namely material orientation, product design orientation, and manufacturing process orientation. The research conducted by Jeya Girubha and Vinodh [24] is an example of sustainable manufacturing research in the level of material orientation. Jeya Girubha and Vinodh [24] used fuzzy VIKOR technique for selecting alternate material for instrument panel used in the electric car by considering environmental impacts assessment. The research conducted by Danglico and Pujari [25] is an example of sustainable manufacturing research in the level of product design orientation. Dangelico and Pujari [25] proposed a conceptual framework that offerings three important environmental dimensions of green product innovation such as materials reduction, energy minimization, and pollution prevention as identified in the life cycle phases of products. Then, the research conducted by Zhang et al [26] is an example of sustainable manufacturing research in the level of process orientation. Zhang et al [26] propose a three-layered framework for Process-oriented
Information Model development and utilization, which can evaluate energy consumption for different processes under a generalized information core.

The level of sustainable manufacturing process can be assessed through several approaches. Szekely and Knirsch [27] explained the metric can be used for assessing the achievement of sustainability (as an example economic, environmental and social) and also explained the method and tools can be used for assessing sustainability performance in numerous manufacturing organizations such as sustainability indices and performance indicators. Szekely and Knirsch [27] concluded that there is a great variance in assessing and recording the sustainability performance. Krajnc and Glavic [28] proposed a model for calculating and comparing the sustainability performance of companies (index of sustainable) in three aspects, namely economic, environmental and societal. In this case, Krajnc and Glavic [28] calculating the sustainability performance based on four economic indicators, six environmental indicators, and four societal. Kasarda et al [29] have applied a design methodology, DFAD (Design for adaptability) to attain sustainable design and modeled the product as a dynamic acceptable system and controllable system with feedback to allow it to adaptable to different product performance criteria. Howarth and Hadfield [30] observed the sustainable development risks and benefits related with any part design to increase the sustainability and also propose to use and disposal finished product and select the raw material in order to reduce the impact of the product to the environmental

\section{Method of Research}

\subsection{Conceptual model}

This study uses a conceptual model from Vimal et al [11] as a basic model. This is a comprehensive model for assessing the manufacturing process sustainability and this model focus on three bottom lines from Elkington [31]. The conceptual model from Vimal et al [11] consists of three levels. The first level consists of three enablers, namely environmental sustainability, social sustainability, and economic sustainability. The second level consists of thirty criteria, divided among three enablers. The third level consists of ninety attributes. However, as this study has the different object of the study compared to Vimal et al [11], the validation process should be conducted to exclude some attributes and criteria that do not comply with the object of study. Finally, after the validation process, this study only uses eighteen criteria and forty-eight attributes. In detail, the enabler, final criteria, and final attributes used in this study can be seen in Table 1 .

\subsection{Data collection procedure}

For assessing the manufacturing process sustainability at the CV. Indo Jati Utama, an expert team was formed which consist of one general manager and four heads of 
various departments (production planning and inventory control department, marketing department, finance department, and human resources department). The expert team was asked to give the weight for each criterion and attribute. The sum of weights of attributes from a certain criterion must be equal to one. The sum of the weight of criteria from a certain enabler also must be equal to one. The expert team was also asked to fill the closed-end questionnaire with five grade scale (the value 8-10 indicated 'extremely sustainable', the value 6-8 indicated 'sustainable', the value 4-6 indicated 'generally sustainable', the value 2-4 indicated 'not sustainable' and the value less than 2 indicated 'extremely sustainable). The grading scale is used for asking the performance rating of each attribute towards specific criteria. This scale was developed by Vinodh [2] and Yang and Li [32]. The responses obtained from the experts about the weight of each criterion and attribute and also the performance rating of each attribute can be seen in Table 1.

\subsection{Data processing procedure}

This study uses Multi-grade Fuzzy (MGF) to assess the manufacturing process sustainability. According to reference Yang and Li [32], the stages of processing data using MGF can be described as follows

- After the team of experts give the weight for each criterion and attribute and also performance rating of each attribute, we should conduct a primary assessment calculation using equation (1) to find a single factor vector for the criterion level.

$$
U_{i j}=\left[\begin{array}{lll}
W_{i j k} & \cdots & W_{i j n}
\end{array}\right] \times\left[\begin{array}{ccc}
A_{11} & \cdots & A_{i 1} \\
\vdots & x_{i} & \vdots \\
A_{k 1} & \cdots & A_{k 1}
\end{array}\right]
$$

Where $W_{i j n}$ represents weights obtained from expert team for enabler $i_{\text {th }}$ criterion $j_{\text {th }}$ attribute $n$th and $\left[\begin{array}{lll}A_{11} & \cdots & A_{k l}\end{array}\right]$ represents performance rating for certain attributes obtained from $\mathrm{k}_{\text {th }}$ expert.

- The second step, conduct a secondary assessment calculation using equation (2) to find a single factor vector for enabler level.

$U_{i}=\left[\begin{array}{lll}W_{i j} & \cdots & W_{i n}\end{array}\right] \times\left[\begin{array}{ccc}U_{i j} & \cdots & U_{i j} \\ \vdots & \cdots & \vdots \\ U_{i n} & \cdots & U_{i n}\end{array}\right]$

Where $W_{i n}$ represents weights from enabler $i_{\text {th }}$ criterion $\mathrm{n}_{\text {th }}$ and $\left[\begin{array}{lll}U_{i n} & \cdots & U_{i n}\end{array}\right]$ represents matrix resulted from the first calculation (single factor vector for the criterion level)

- Synthetic assessment is calculated using equation (3). It is calculated by multiply the weights of each enabler from the team of experts and single factor vector obtained from secondary assessment calculation.

$$
U=\left[\begin{array}{lll}
W_{i} & \cdots & W_{n}
\end{array}\right] \times\left[\begin{array}{ccc}
U_{i} & \cdots & U_{i} \\
\vdots & \cdots & \vdots \\
U_{n} & \cdots & U_{n}
\end{array}\right]
$$

Where $W_{n}$ represents weights from enabler nth and $\left[\begin{array}{lll}U_{n} & \ldots & U_{n}\end{array}\right]$ represents matrix form from second assessment calculation. Then, the results were converted into crisp values to be Process Sustainability Index (PSI) using equation (4).

$$
P S I=\frac{\Sigma(U \times W)}{\text { sum of expert }}
$$

- The performance importance index (PII) is calculated using equation (5). The higher the PII of a factor is, the lower the degree of contribution for this factor is.

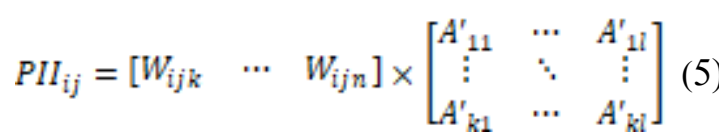

\section{Result and Discussion}

The responses obtained from the experts about the weight of each criterion and attribute and also the performance rating of each attribute can be seen in Table 1.

Primary assessment calculation. The weight and performance rating in Table 1 becomes an input to conduct a primary assessment calculation using equation (1). The example of primary assessment calculation is pertaining to attribute of the criterion flexibility and response to change which is belong to enabler economic. This criterion has three attributes, namely production flexibility, market flexibility, and retrofitting of machine tools. As seen in Table 1, the attribute in criterion flexibility and response to change have weight $\left[\begin{array}{lll}0.5 & 0.3 & 0.2\end{array}\right]$ and the vector of performance rating of the attribute in the criterion flexibility and response to change can be written as follow

$\left[\begin{array}{llll}7 & 7 & 67 & 5 \\ 8 & 8 & 77 & 5 \\ 6 & 8 & 86 & 6\end{array}\right]$

So, the primary assessment calculation for the attribute in the criterion flexibility and response to change can be written as follow

$$
\begin{aligned}
& U_{11}=\left[\begin{array}{lll}
0.5 & 0.3 & 0.2
\end{array}\right] \times\left[\begin{array}{llll}
7 & 7 & 67 & 5 \\
8 & 8 & 77 & 5 \\
6 & 8 & 86 & 6
\end{array}\right] ; \\
& U_{11}=\left[\begin{array}{lllll}
7.1 & 7.5 & 6.7 & 6.8 & 5.2
\end{array}\right]
\end{aligned}
$$


Table 1. The Weight of Each criterion and Attribute and also the Performance Rating of Each Attribute

\begin{tabular}{|c|c|c|c|c|c|c|c|c|c|c|}
\hline \multirow[t]{2}{*}{ Enabler } & \multirow[t]{2}{*}{ Criteria } & \multirow[t]{2}{*}{ Attributes } & \multicolumn{3}{|c|}{ Weight } & \multicolumn{5}{|c|}{ Performance Rating } \\
\hline & & & Enabler & Criteria & Attributes & E1 & E2 & E3 & E4 & E5 \\
\hline \multirow{17}{*}{$\begin{array}{l}\text { Economy } \\
\text { (U11) }\end{array}$} & \multirow{3}{*}{$\begin{array}{l}\text { Flexibility and } \\
\text { response to } \\
\text { changes (U11) }\end{array}$} & Production flexibility & \multirow{17}{*}{0.35} & \multirow{3}{*}{0.3} & 0.5 & 7 & 7 & 6 & 7 & 5 \\
\hline & & Market flexibility & & & 0.3 & 8 & 8 & 7 & 7 & 5 \\
\hline & & Retrofitting of machine tools & & & 0.2 & 6 & 8 & 8 & 6 & 6 \\
\hline & \multirow[t]{3}{*}{$\begin{array}{l}\text { Operating controls } \\
\text { (U12) }\end{array}$} & $\begin{array}{l}\text { Development of SOP } \\
\text { (Standard Operating } \\
\text { Procedure) }\end{array}$ & & \multirow{3}{*}{0.2} & 0.2 & 8 & 10 & 8 & 8 & 6 \\
\hline & & $\begin{array}{l}\text { Monitoring and observation } \\
\text { of equipment performance }\end{array}$ & & & 0.4 & 8 & 9 & 9 & 9 & 5 \\
\hline & & $\begin{array}{l}\text { Operation controls activated } \\
\text { through in-line monitoring }\end{array}$ & & & 0.4 & 9 & 9 & 8 & 9 & 5 \\
\hline & \multirow{3}{*}{$\begin{array}{l}\text { Reciprocal } \\
\text { arrangements } \\
\text { (U13) }\end{array}$} & $\begin{array}{l}\text { Two organizations to back } \\
\text { each other up }\end{array}$ & & \multirow{3}{*}{0.2} & 0.3 & 8 & 9 & 9 & 8 & 6 \\
\hline & & $\begin{array}{l}\text { Organization to use each } \\
\text { other's resources }\end{array}$ & & & 0.4 & 8 & 8 & 8 & 8 & 6 \\
\hline & & $\begin{array}{l}\text { Rendering assistance to each } \\
\text { other }\end{array}$ & & & 0.3 & 8 & 9 & 9 & 8 & 5 \\
\hline & \multirow[t]{3}{*}{$\begin{array}{l}\text { Maintainability } \\
\text { (U14) }\end{array}$} & $\begin{array}{l}\text { Analysis of repetitive } \\
\text { equipment failure }\end{array}$ & & \multirow{3}{*}{0.1} & 0.6 & 7 & 7 & 7 & 6 & 7 \\
\hline & & $\begin{array}{l}\text { Evaluation of maintenance } \\
\text { cost and alternatives }\end{array}$ & & & 0.2 & 7 & 8 & 7 & 7 & 5 \\
\hline & & $\begin{array}{l}\text { Formation of new strategies } \\
\text { to prevent failure }\end{array}$ & & & 0.2 & 9 & 9 & 8 & 9 & 5 \\
\hline & \multirow[t]{2}{*}{ Defect ratio(U15) } & Proper inspection plan & & \multirow[b]{2}{*}{0.15} & 0.6 & 7 & 9 & 9 & 7 & 6 \\
\hline & & $\begin{array}{l}\text { Quality improvement } \\
\text { program }\end{array}$ & & & 0.4 & 10 & 10 & 9 & 10 & 6 \\
\hline & \multirow[t]{3}{*}{$\begin{array}{l}\text { Testing methods } \\
\text { (U16) }\end{array}$} & $\begin{array}{l}\text { Availability of testing } \\
\text { equipment }\end{array}$ & & \multirow{3}{*}{0.05} & 0.2 & 9 & 9 & 8 & 8 & 5 \\
\hline & & SOP for testing & & & 0.4 & 9 & 9 & 9 & 9 & 7 \\
\hline & & $\begin{array}{l}\text { Efforts to improve testing } \\
\text { efficiency }\end{array}$ & & & 0.4 & 8 & 8 & 8 & 8 & 6 \\
\hline \multirow{13}{*}{$\begin{array}{l}\text { Environm } \\
\text { ental } \\
\text { (U2) }\end{array}$} & \multirow{2}{*}{$\begin{array}{l}\text { Management for } \\
\text { hazardous } \\
\text { substances } \\
\text { (U21) }\end{array}$} & $\begin{array}{l}\text { Safety handling. use and } \\
\text { transportation of materials }\end{array}$ & \multirow{13}{*}{0.35} & \multirow[b]{2}{*}{0.05} & 0.6 & 7 & 8 & 8 & 8 & 6 \\
\hline & & $\begin{array}{l}\text { Action towards hazardous } \\
\text { material substance } \\
\text { minimization }\end{array}$ & & & 0.4 & 8 & 8 & 8 & 8 & 5 \\
\hline & \multirow[t]{2}{*}{$\begin{array}{l}\text { Environmental } \\
\text { management } \\
\text { (U22) }\end{array}$} & $\begin{array}{l}\text { Technological awareness } \\
\text { which helps in decision- } \\
\text { making }\end{array}$ & & 0.15 & 0.6 & 6 & 7 & 7 & 6 & 6 \\
\hline & & $\begin{array}{l}\text { Formulation of in-house } \\
\text { technologies and principles }\end{array}$ & & & 0.4 & 7 & 7 & 7 & 7 & 6 \\
\hline & Waste & Waste collection mechanism & & & 0.5 & 7 & 9 & 8 & 7 & 7 \\
\hline & $\begin{array}{l}\text { management } \\
\text { (U23) }\end{array}$ & $\begin{array}{l}\text { Appropriate methodology } \\
\text { for waste processing }\end{array}$ & & 0.3 & 0.5 & 7 & 8 & 7 & 7 & 5 \\
\hline & $\begin{array}{l}\text { Environmental } \\
\text { friendliness }\end{array}$ & $\begin{array}{l}\text { Usage of eco-friendly } \\
\text { materials }\end{array}$ & & & 0.5 & 8 & 9 & 8 & 8 & 5 \\
\hline & (U24) & $\begin{array}{l}\text { Design to improve eco- } \\
\text { friendly nature of product } \\
\text { (design for environment) }\end{array}$ & & 0.25 & 0.5 & 9 & 10 & 8 & 9 & 6 \\
\hline & $\begin{array}{l}\text { End of Life } \\
\text { disposal }\end{array}$ & $\begin{array}{l}\text { Clean development } \\
\text { mechanism practice }\end{array}$ & & 0.15 & 0.6 & 9 & 8 & 9 & 9 & 5 \\
\hline & (U25) & Land fill & & & 0.4 & 9 & 9 & 9 & 9 & 5 \\
\hline & Green image & Contribution to society & & & 0.2 & 7 & 8 & 8 & 7 & 7 \\
\hline & (U26) & Innovative forward looking & & 0.1 & 0.2 & 6 & 9 & 7 & 7 & 7 \\
\hline & & Green marketing & & & 0.6 & 7 & 7 & 7 & 7 & 5 \\
\hline Social & Employee & Reward valued behavior & & & 0.3 & 5 & 8 & 7 & 7 & 5 \\
\hline (U3) & $\begin{array}{l}\text { compensation } \\
\text { practices (U31) }\end{array}$ & $\begin{array}{l}\text { Ensure equity and motivate } \\
\text { to retain staff }\end{array}$ & & 0.05 & 0.7 & 5 & 8 & 8 & 7 & 5 \\
\hline & $\begin{array}{l}\text { Enforcement for } \\
\text { socio- }\end{array}$ & $\begin{array}{l}\text { Culture for socio-economic } \\
\text { performance }\end{array}$ & & & 0.3 & 8 & 10 & 8 & 8 & 5 \\
\hline & $\begin{array}{l}\text { environmental } \\
\text { performance (U32) }\end{array}$ & $\begin{array}{l}\text { Compliance to government } \\
\text { regulations }\end{array}$ & & 0.2 & 0.4 & 9 & 8 & 9 & 9 & 5 \\
\hline & & $\begin{array}{l}\text { Conduct of awareness } \\
\text { programs }\end{array}$ & 0.3 & & 0.3 & 9 & 9 & 9 & 9 & 5 \\
\hline & $\begin{array}{l}\text { Implication of } \\
\text { health hazards and }\end{array}$ & $\begin{array}{l}\text { Usage of personal protection } \\
\text { equipment }\end{array}$ & & & 0.4 & 9 & 10 & 9 & 9 & 5 \\
\hline & its practices (U33) & $\begin{array}{l}\text { Toxicity of product and time } \\
\text { of exposure of product if } \\
\text { inhaled }\end{array}$ & & 0.3 & 0.3 & 7 & 8 & 8 & 7 & 5 \\
\hline
\end{tabular}




\begin{tabular}{|c|c|c|c|c|c|c|c|c|c|c|}
\hline \multirow[t]{11}{*}{ Enabler } & \multirow[t]{3}{*}{ Criteria } & Attributes & \multicolumn{3}{|c|}{ Weight } & \multicolumn{5}{|c|}{ Performance Rating } \\
\hline & & & Enabler & Criteria & Attributes & E1 & E2 & E3 & E4 & E5 \\
\hline & & $\begin{array}{l}\text { Magnitude and time of } \\
\text { exposure to noise }\end{array}$ & & & 0.3 & 7 & 9 & 9 & 7 & 5 \\
\hline & \multirow{3}{*}{$\begin{array}{l}\text { Employee career } \\
\text { development } \\
\text { program } \\
\text { (Employee } \\
\text { Training and } \\
\text { orientation) (U34) }\end{array}$} & Human rights & & \multirow{3}{*}{0.25} & 0.4 & 7 & 8 & 8 & 7 & 6 \\
\hline & & $\begin{array}{l}\text { Training season in advance } \\
\text { manufacturing process and } \\
\text { evaluation for continuous } \\
\text { improvement }\end{array}$ & & & 0.4 & 6 & 8 & 7 & 6 & 6 \\
\hline & & $\begin{array}{l}\text { Evaluation for continuous } \\
\text { improvement }\end{array}$ & & & 0.2 & 6 & 8 & 7 & 7 & 6 \\
\hline & \multirow[t]{3}{*}{$\begin{array}{l}\text { Employee } \\
\text { involvement (U35) }\end{array}$} & $\begin{array}{l}\text { Employee recognition } \\
\text { through appraisal schemes }\end{array}$ & & \multirow{3}{*}{0.1} & 0.2 & 8 & 8 & 10 & 8 & 6 \\
\hline & & $\begin{array}{l}\text { Involvement of employee in } \\
\text { group decision-making }\end{array}$ & & & 0.4 & 8 & 8 & 9 & 9 & 6 \\
\hline & & $\begin{array}{l}\text { Strong employee sprit and } \\
\text { cooperation }\end{array}$ & & & 0.4 & 8 & 9 & 10 & 9 & 6 \\
\hline & \multirow{2}{*}{$\begin{array}{l}\text { Macro social } \\
\text { performance (U36) }\end{array}$} & Macroeconomic welfare & & \multirow{2}{*}{0.1} & 0.4 & 9 & 10 & 8 & 8 & 5 \\
\hline & & Legislation and enforcement & & & 0.6 & 9 & 10 & 10 & 9 & 5 \\
\hline
\end{tabular}

In the same way, the primary assessment calculation for the attribute in the other criterion is calculated and the result can be seen as follow.

$$
\begin{aligned}
& \text { Economic } \\
& U_{11}=\left[\begin{array}{lllll}
7.1 & 7.5 & 6.7 & 6.8 & 5.2
\end{array}\right] \\
& U_{12}=\left[\begin{array}{lllll}
8.4 & 9.2 & 8.4 & 8.8 & 5.2
\end{array}\right] \\
& U_{13}=\left[\begin{array}{lllll}
8.0 & 8.6 & 8.6 & 8.0 & 5,7
\end{array}\right] \\
& U_{14}=\left[\begin{array}{lllll}
7.4 & 7.6 & 7.2 & 6.8 & 6.2
\end{array}\right] \\
& U_{15}=\left[\begin{array}{lllll}
8.2 & 9.4 & 9.0 & 8.2 & 6.0
\end{array}\right] \\
& U_{16}=\left[\begin{array}{lllll}
8.6 & 8.7 & 8.4 & 8.4 & 6.1
\end{array}\right] \\
& \text { Social } \\
& U_{31}=\left[\begin{array}{lllll}
5.0 & 8.0 & 7.7 & 7.0 & 5.0
\end{array}\right] \\
& U_{32}=\left[\begin{array}{lllll}
8.7 & 8.9 & 8.7 & 8.7 & 5.0
\end{array}\right] \\
& U_{33}=\left[\begin{array}{lllll}
7.8 & 9.1 & 8.7 & 7.8 & 5.0
\end{array}\right] \\
& U_{34}=\left[\begin{array}{lllll}
6.4 & 8.0 & 7.4 & 6.6 & 6.0
\end{array}\right] \\
& U_{35}=\left[\begin{array}{lllll}
8.0 & 8.0 & 9.6 & 8.8 & 6.0
\end{array}\right] \\
& U_{36}=\left[\begin{array}{lllll}
9.0 & 10.0 & 9.2 & 8.6 & 5.0
\end{array}\right]
\end{aligned}
$$

\section{Environmental}

$U_{21}=\left[\begin{array}{lllll}7.4 & 8.0 & 8.0 & 8.0 & 5,6\end{array}\right]$

$U_{22}=\left[\begin{array}{lllll}6.4 & 7.0 & 7.0 & 6.4 & 6.0\end{array}\right]$

$U_{23}=\left[\begin{array}{lllll}7.0 & 8.5 & 7.5 & 7.0 & 6.0\end{array}\right]$

$U_{24}=\left[\begin{array}{lllll}8.5 & 9.5 & 8.0 & 8.5 & 5.5\end{array}\right]$

$U_{25}=\left[\begin{array}{lllll}9.0 & 8.4 & 9.0 & 9.0 & 5.0\end{array}\right]$

$U_{26}=\left[\begin{array}{lllll}6.8 & 7.6 & 7.2 & 7.0 & 5.8\end{array}\right]$

Secondary assessment calculation. The result from primary assessment calculation becomes an input for a secondary assessment calculation. This is the example of secondary assessment calculation for criterion of economic sustainability enabler. The economic sustainability enabler consists of six criteria. Weights pertaining to criteria of economic sustainability enabler are given as $\left[\begin{array}{llllll}0.3 & 0.2 & 0.2 & 0.1 & 0.15 & 0.05\end{array}\right]$; whereas, the vector of performance rating of the criterion in the economic sustainability enabler can be written as follow

$\left[\begin{array}{lllll}7.1 & 7.5 & 6.7 & 6.8 & 5.2 \\ 8.4 & 9.2 & 8.4 & 8.8 & 5.2 \\ 8.0 & 8.6 & 8.6 & 8.0 & 5.7 \\ 7.4 & 7.6 & 7.2 & 6.8 & 6.2 \\ 8.2 & 9.4 & 9.0 & 8.2 & 6.0 \\ 8.6 & 8.7 & 8.4 & 8.4 & 6.1\end{array}\right]$

Using equation (2) the results of secondary assessment for the criterion in the economic sustainability enabler can be seen as follow

\section{$U_{1}=\left[\begin{array}{lllll}7.81 & 8.42 & 7.90 & 7.73 & 5.57\end{array}\right]$}

Then, the sustainability index of economic can be calculated as follow.

$$
U_{1}=\frac{7.81+8.42+7.90+7.73+5.57}{5}=7.48
$$

In the same way, the secondary assessment for the criterion in the environmental and social enabler and the sustainability index of environmental and social enabler are calculated and the result can be seen as follow.

$$
\begin{aligned}
& U_{2}=\left[\begin{array}{lllll}
7.59 & 8.40 & 7.77 & 7.64 & 5.69
\end{array}\right]=7.41 \\
& U_{3}=\left[\begin{array}{lllll}
7.63 & 8.75 & 8.47 & 7.82 & 5.35
\end{array}\right]=7.60
\end{aligned}
$$

Synthetic assessment calculation. The synthetic assessment calculation is used to calculate the composite value of process sustainability index. As seen in Table 1, the weight pertaining for overall enabler as given as $\left[\begin{array}{lll}0.35 & 0.35 & 0.30\end{array}\right]$ and the result of secondary assessment calculation for the criterion in each enabler is given by

$$
\left[\begin{array}{ccccc}
7.81 & 8.42 & 7.9 & 7.73 & 5.57 \\
7.59 & 8.40 & 7.77 & 7.64 & 5.69 \\
7.63 & 8.75 & 8.47 & 7.82 & 5.35
\end{array}\right]
$$

So, using equation (3), the results of synthetic assessment is $U=\left[\begin{array}{lllll}7.68 & 8.51 & 8.02 & 7.72 & 5.54\end{array}\right]$ and the process sustainability index (PSI) is calculated using equation (4).

$$
P S I=\frac{7.68+8.51+8.02+7.72+5.54}{5}=7.495
$$

The performance importance index. The performance importance index (PII) is calculated using equation (5). This is the example of PII calculation for criterion flexibility and response to change which have three attributes (production flexibility, market flexibility, and retrofitting of machine tool).

In the same way, the value of PII for other criterion is calculated and the result can be seen below

$$
\begin{aligned}
& P I I_{11}=\left[\begin{array}{lll}
W_{111} & W_{112} & W_{113}
\end{array}\right] \times\left[\begin{array}{llll}
A_{11}^{\prime} & A_{12}^{\prime} & A_{13}^{\prime} A_{14}^{\prime} & A_{15}^{\prime} \\
A_{21}^{\prime} & A_{22}^{\prime} & A_{23}^{\prime} A_{24}^{\prime} & A_{25}^{\prime} \\
A_{31}^{\prime} & A_{32}^{\prime} & A_{33}^{\prime} A_{34}^{\prime} & A_{35}^{\prime}
\end{array}\right] \\
& P I I_{11}=\left[\begin{array}{lll}
0.50 & 0.30 & 0.20
\end{array}\right] \times\left[\begin{array}{llll}
3 & 3 & 43 & 5 \\
2 & 2 & 33 & 5 \\
4 & 2 & 24 & 4
\end{array}\right] \\
& P I I_{11}=\left[\begin{array}{lllll}
2.90 & 2.50 & 3.30 & 3.20 & 4.80
\end{array}\right] \\
& P I_{11}=\frac{2.9+3.5+3.3+3.2+4.8}{5}=3.34
\end{aligned}
$$

In the same way, the value of PII for other criterion is calculated and the result can be seen below 


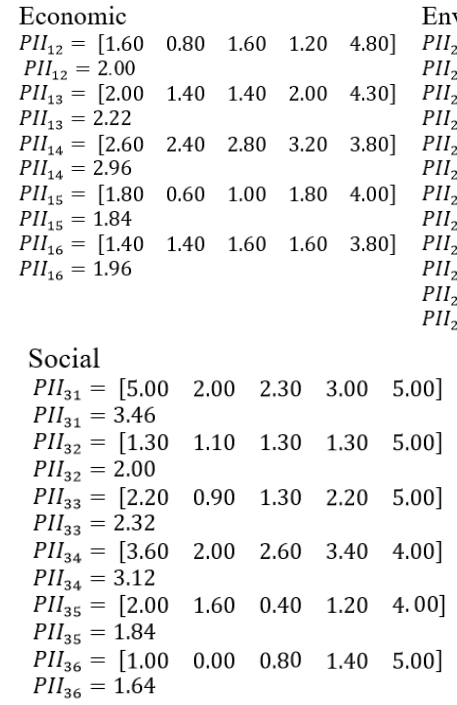

Identify Drag Factors. A gap analysis was done to identify the drag factors. A value of PII of each criterion is used to identify the associated drag factors. The value of 3 is set as the threshold value. A criterion is stated as an obstacle to achieving sustainability if the value of PII of that criterion higher than a threshold value or higher than 3. In detail, the comparison between the value of PII of each criterion and the threshold value can be seen in Figure 1. As seen in Figure 1, there are 5 criteria which have the value of PII higher than 3, namely flexibility and response to changes (3.34), environmental management (3.44), green image (3.12), employee compensation practices (3.46), and employee career development program (3.12). There is some proposal improvement proposed in this study based on those five criteria. First, the company should make a business evaluation periodically, maybe every 6 months or once a year. This evaluation is conducted to see whether the company needs to make changes because of the demands of changes from the consumers and competition. Second, in order to increase environmental management, the company can consider implementing ISO 14000:2015 or joint PROPER program carried out by the Ministry of Environment (KLH). Third, to increase a green image, the company can consider making a sustainability report so that company sustainability performance can be directly assessed by society. Fourth, to increase employee compensation practices, the company can consider implementing a reward system for performance achieved by its employees. Fifth, to increase the employee career development program, the company can consider to redesign the job, make a job rotation and career paths

\section{Conclusion}

This study focuses on the assessment of manufacturing process sustainability at CV. Indo Jati Utama. The assessment is based on three enablers (environmental sustainability, social sustainability, and economic sustainability), 18 criteria and 48 attributes. Among the three enablers, the social enabler has the highest score of sustainability index (7.60), followed by economic enabler (7.48) and environmental enabler (7.42).

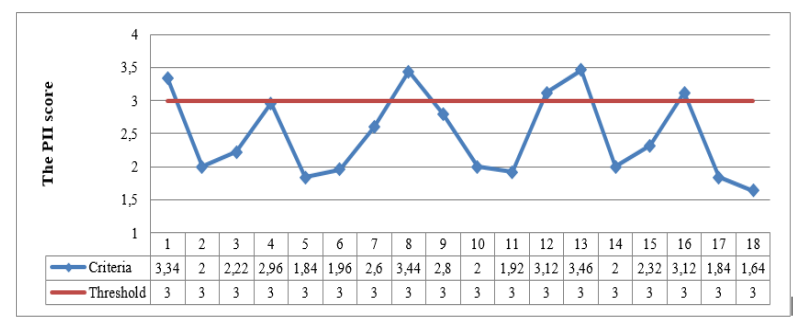

Fig. 1. Drag factors

The sustainability index is 7.50. Although all of those value indicating the condition of sustainability, there were five criteria should be improved to make the enterprise more sustainable, namely flexibility and response to changes, environmental management, green image, employee compensation practices, and employee career development program. Compare to the threshold value suggested by the company, those five indicators have performance importance index higher than 3 . In this case, the criterion is stated as an obstacle as this criterion has the value of PII higher than 3 .

\section{References}

1. A.M. Duda, M.T. El-Ashry, Water Int. of IWRA 25, 115-126 (2000)

2. S. Vinodh, Clean Technol. Environ. Policy 13, 509515 (2011)

3. K.E.K. Vimal, S. Vinodh, J. Manuf. Technol. Mana. 24, 274-292 (2013)

4. R.K. Singh, H.R. Murty, S.K. Gupta, A.K. Dikshit, Ecol. Indic. 15, 281-299 (2012)

5. C. Nzila, J. Dewulf, H. Spanjers, D. Tuigong, H. Kiriamiti, H.V. Langenhove, Appl. Energ. 93, 496506 (2012)

6. S. Vinodh, K. Jayakrishna, V. Kumar, R. Dutta, Clean Technol. Environ. Policy 16, 163-174 (2014)

7. R. Verheem, J. Tonk, IAPA 18, 177-182 (2000)

8. C.T. Lin, H. Chiu, Y. Chu, Int. J. Prod. Econ. 100, 285-299 (2006)

9. S. Vinodh, S.K. Chintha, Int. J. Prod. Res. 49, 431445 (2011)

10. S. Vinodh, K.E.K. Vimal, Int. J. Adv. Manuf. Technol. 60, 1185-1195 (2012)

11. K.E.K. Vimal, S. Vinodh, R. Muralidharan, Int. J. Sustain. Eng. 8, 40-54 (2014)

12. M. Despeisse, F. Mbaye, P.D. Ball, A. Levers, Prod. Plan. Control 23, 354-376 (2012)

13. A. Gunasekaran, A. Spalanzani, Int. J. Prod. Econ. 140, 35-47 (2011)

14. N. Habidin, A. Zubir, J. Conding, N. Jaya, S. Hashim, WREMSD 9, 515-529 (2013)

15. M. Garetti, M. Taisch, Prod. Plan. Control: Mana. Op. 23, 83-104 (2012)

16. G. Ulusoy, I. Ikiz, IJOPM 21, 1020-1043 (2001) 
17. T. Jackson, Industrial ecology and cleaner production: a handbook of industrial ecology (Edward Elgar Publication Limited, UK, 2002)

18. C. Rusinko, IEEE T. Eng. Manage. 54, 445-454 (2007)

19. G. Hu, IJSM 2, 338-355 (2012)

20. S. Rahimifard, A. Clegg, Int. J. Prod. Res. 45, 40134019 (2007)

21. S. Jafartayari, Awareness of sustainable manufacturing practices in Malaysia manufacturers (Thesis, Universiti Teknologi Malaysia, 2010)

22. F. Nabhani, M. Mckie, S. Hodgson, IJSM 3, 1-19 (2013)

23. D.T. Phama, O.A. Williams, A.J. Thomas, R. Barton, Z. Ebrahim, T. Shamsuddin, J. Manuf. Technol. Mana. 23, 103-123 (2011)

24. R. Jeya Girubha, S. Vinodh, Mater. Des. 37, 478486 (2012)

25. R. Dangelico, P. Devashish, J. Bus. Ethics 95, 471486 (2010)

26. H. Zhang, B. Zhu, Y. Li, O. Yaman, U. Roy, J. Manuf. Syst. 37, 459-466 (2015)

27. F. SzeKely, M. Knirsch, EMJ 23, 628-647 (2005)

28. D. Krajnc, P. Glavic, Ecol. Econ. 55, 551-563 (2005)

29. M.E. Kasarda, J.P. Terpenny, J. Park, Robot. Comput. Integr. Manuf. 23, 727-734 (2007)

30. M. Howarth, A. Hadfield, Mater. Des. 27, 11281133 (2006)

31. J. Elkington, Cannibals with forks: the triple bottom line of 21st century (New Society Publishers, Business Gabriola Island, 1997)

32. S.L. Yang, T.F. Li, J. Mater. Process. Technol. 129, 640-644 (2002) 